\title{
The influence of age on lipid profile among women taking hormonal contraceptives
}

\author{
Chukwubike Udoka OKEKE ${ }^{1 *}$, Solomon A. BRAIDE ${ }^{2}$, Jervase EKEZIE ${ }^{1}$ and \\ Bartholomew Ngozika OKWANDU ${ }^{3}$ \\ ${ }^{I}$ Department of Orthopaedic and Prosthesis, Federal University of Science and Technology, \\ Owerri, Imo State, Nigeria. \\ ${ }^{2}$ Department of Medical Laboratory Science, Rivers State University of Science and Technology, \\ Port Harcourt, Rivers State, Nigeria. \\ ${ }^{3}$ Department of Biochemistry, Madonna University, Elele, Rivers State, Nigeria. \\ "Corresponding author, E-mail: jer32vs27@yahoo.com, Phone; +2348037353551
}

\begin{abstract}
Family planning clinic and women at large, in Port Harcourt, Rivers State, have adopted the administration of hormonal contraceptives to cub incessant occurrence of unplanned pregnancies among women within the reproduction age. This study was carried out to evaluate the effect of hormonal contraceptives (Medroxyprogesterone acetate or Norethisterone oenanthate) on lipid profile of premenopausal women at different age groups. Total cholesterol (TC), Triglycerides (TG), High-Density Lipoprotein Cholesterol (HDL-C) and Low Density Lipoprotein Cholesterol (LDL-C), of both women who were users and non-users of hormonal contraceptives at different age groups (16-25, 26-35, and 36-45 years of age) were estimated using enzymatic method. There were raised levels of TG, TC, HDL-C and reduced level of LDL-C among women taking hormonal contraceptives. The increase levels of TC and HDL-C in women within the age range of 26-35 years was significant $(\mathrm{p} \leq 0.05)$. The result obtained suggested that the use of hormonal contraceptives do not impose any cardiovascular risk among these women in all age groups, rather, a beneficial effect. Women within the age range of 26-35 years by this study, had effect that is more beneficial because they had significantly high levels of TC and HDL-C, and reduced Castelli risk index I and II (TC/HDL-C and LDL-C/HDL-C respectively).
\end{abstract}

(C) 2011 International Formulae Group. All rights reserved.

Keywords: Contraceptives, age, lipids, cardiovascular.

\section{INTRODUCTION}

Unplanned pregnancies have driven women to resort to different types of contraception (which include hormonal and non-hormonal methods of contraception). Hormonal contraception has been one of the most effective reversible methods, and however the method of choice among women and family planning clinics (Lech 2003). Waine et al. (1963) noted that until 1960s attention was not drawn to the adverse metabolic effect of the contraceptive hormones. These hormonal contraceptives are estrogen and/or progesterone based compounds whose effects involve not only on the uterus or ovaries, but also on other body 
tissues like skin, brain, arteries and veins (Speroff and Darney 1992, Helena et al., 2003). It has been suggested that those women receiving hormonal contraceptives develop a series of metabolic effects, which include raised serum lipid and lipoprotein concentrations (Sheu et al., 1994; Guazzelli et al., 2005). Barr et al. (1951) and Nikkila et al., 1953) demonstrated that relative or absolute decrease in the Cholesterol carried in the HDL-fraction of plasma was seen in atherosclerotic patients, and therefore stated that impaired catabolism of Chylomicron remnant, Intermediate Density Lipoprotein (IDL), and Low Density LipoproteinCholesterol (LDL-C) are associated with atherosclerosis. Disruption in the catabolism of these three atheriogenic lipoproteins gives rise to increase in serum Cholesterol that can result in atherosclerosis.

The alterations in lipid metabolism that occur with the use of hormonal contraceptive have aroused considerable concern that hormonal contraceptives might increase the risk of premature atherosclerosis (Teichman 1995). Stadel (1981) also noted that hormonal contraceptives have been implicated in the increase in incidence of cardiovascular and thromboemoblic disease. According to Brezinka and Padmos (1994), the effect is dose dependent.

The two basic constituents of hormonal contraceptives, estrogen and progestin, have different effects on lipid metabolism. Estrogen tends to have favourable effect by increasing serum Triglyceride and HDL-C concentration, and reducing LDL-C concentration (LaRosa et al., 1989), while progestin, depending on dose and formulation, may have opposite effect (Ottoson 1984), except third generation progestin such as desogestrel (Lobo et al., 1996). Lobo et al. (1996) also observed that long use of combined hormonal contraceptives containing desogestrel and ethinyl estradiol increases LDL-C, and this gives a potential cardio-protective benefit.

The effect of age on lipid profiles among women taking hormonal contraceptives has not been considered, and this prompted this study. This study was set to determine the age groups of women who are more favorable to use hormonal contraceptives. Lipid profiles of this group of women, at different age groups, residing in Port Harcourt, were evaluated in this study.

\section{MATERIALS AND METHODS}

This study was carried out in Port Harcourt, the capital city of Rivers State, Nigeria. A random selection of 100 premenopausal women of different ages, grouped into three, thus: 16 to 25 years, 26 to 35 years, 36 to 45 years. These women were apparently healthy, non-pregnant, premenopausal and non-breast-feeding. Fifty of the women who were non users of contraceptives were used as control group, while the rest fifty were users of hormonal contraceptive drugs for at least 3 months before sample collection, and these women were attending Family Planning Units of two Primary Health Centers in Port Harcourt. The hormonal contraceptives used for this study were Medroxyprogesterone acetate (MPA) or Norethisterone oenanthate (NEO) and each were administered to the women appropriately.

A fasting blood sample of $5 \mathrm{ml}$ volume was obtained from each patient. The serum of the samples was used to estimate the concentrations of Total Cholesterol (TC), Triglyceride (TG), High Density LipoproteinCholesterol (HDL-C), and Low Density Lipoprotein - Cholesterol (LDL-C), colorimetrically using enzymatic method.

\section{Statistical analysis}

The various data collated were analyzed statistically using mean, standard error, students-paired t-test, and probability tests with $\mathrm{P}$-value equal to or less than 0.05 regarded statistically significant $(\mathrm{P} \leq 0.05)$.

\section{RESULTS AND DISCUSSION}

The results obtained were represented in the tables below. Table 1 showed the change in TG, TC, HDL-C and LDL-C levels of women within the age range of $16-25$ 
years. It was observed that higher levels of TG, TC, HDL-C and lower level of LDL-C of the women taking hormonal contraceptive were not statistically significant $(\mathrm{p}>0.05)$.

The levels of TG, TC, HDL-C were higher in this group of women (26-35 years) taking hormonal contraceptive than their counterpart in control group as seen in Table 1 below. LDL-C level of these women was lower than that of the control women. The changes in TC and HDL-C levels were statistically significant $(\mathrm{p}<0.05)$ but the changes in TG and LDL-C level were not statistically significant $(p>0.05)$.

From the same Table 1, it was noticed that hormonal contraceptives did not have any significant effect on the lipid profile $(p>0.05)$ in these women within the age ( $36-45$ years) though there were higher levels of TG, TC and HDL-C and lower level of LDL-C than in the control women, the effect was statistically insignificant $(p>0.05)$.

High levels of TC, TG, HDL-C, and lower levels of LDL-C were observed in every age group considered in this study. This agrees with the findings made by Moutos et al. (1994) and Benajione et al. (1997) on women taking ethinyl estradiol and Gestodene contraceptives. Adekunle et al. (2000) observed raised levels of TG, TC, HDL-C and LDL-C among Nigerian women taking normegestrol acetate - Uniplant. In the study made by Evans and Forinash, there were significantly high levels of TC, TG, HDL-C, and lower level of LDL-C in women that used medroxyprogesterone-Estradiol cypionate injections.

The change in levels in these lipid parameters was not statistically significant except in TC and HDL-C in women within the age group of 26-35 years.

The Castelli index I and 2 (TC/HDL-C and LDL-C/HDL-C ratios) in all age groups were reduced in women on hormonal contraceptives and these showed no risk of cardiovascular disease among these women. This also agrees with the findings of Aldrighi et al. (2004) and Cromie et al. (2000). There was no significant change in level of LDL-Camong the users of hormonal contraceptives.

Table 1: Comparative results of TG, TC, HDL-C AND LDL-C Level in Control and Women on Hormone Contraceptive at different age intervals.

\begin{tabular}{|c|c|c|c|c|c|}
\hline Age interval & $\begin{array}{l}\text { Number of } \\
\text { women }\end{array}$ & TG mmol/l & $\begin{array}{l}\text { TC } \\
\mathrm{mmol} / \mathrm{l}\end{array}$ & $\begin{array}{l}\text { HDL-C } \\
\mathrm{mmol} / \mathrm{l}\end{array}$ & $\begin{array}{l}\text { LDL-C } \\
\mathrm{mmol} / \mathrm{l}\end{array}$ \\
\hline $\begin{array}{l}\text { 16-25 yrs Non- } \\
\text { users }\end{array}$ & 16 & $0.91 \pm 0.05$ & $3.80 \pm 0.11$ & $1.79 \pm 0.19$ & $1.50 \pm 0.17$ \\
\hline $\begin{array}{l}16-25 \text { yrs } \\
\text { Users }\end{array}$ & 10 & $1.04 \pm 0.06$ & $3.83 \pm 0.15$ & $2.32 \pm 0.21$ & $1.07 \pm 0.16$ \\
\hline$P$ value & & $\mathrm{P}>0.05$ & $\mathrm{P}>0.05$ & $\mathrm{P}>0.05$ & $\mathrm{P}>0.05$ \\
\hline $\begin{array}{l}26-35 \text { yrs Non- } \\
\text { users }\end{array}$ & 19 & $0.97 \pm 0.05$ & $3.92 \pm 0.10$ & $1.95 \pm 0.15$ & $1.60 \pm 0.16$ \\
\hline $\begin{array}{l}26-35 \text { yrs } \\
\text { Users }\end{array}$ & 28 & $1.20 \pm 0.12$ & $4.50 \pm 1.19$ & $2.70 \pm 1.19$ & $1.34 \pm 0.17$ \\
\hline$P$ value & & $\mathrm{P}>0.05$ & $\mathrm{P}<0.05$ & $\mathrm{P}<0.05$ & $\mathrm{P}>0.05$ \\
\hline $\begin{array}{l}36-45 \text { yrs Non- } \\
\text { users }\end{array}$ & 14 & $0.91 \pm 0.02$ & $4.01 \pm 0.11$ & $1.73 \pm 0.22$ & $1.89 \pm 0.18$ \\
\hline $\begin{array}{l}36-45 \text { yrs } \\
\text { Users }\end{array}$ & 13 & $1.02 \pm 0.12$ & $4.16 \pm 0.21$ & $2.42 \pm 0.26$ & $1.29 \pm 0.23$ \\
\hline$P$ value & & $P>0.05$ & $\mathrm{P}>0.05$ & $\mathrm{P}>0.05$ & $\mathrm{P}>0.05$ \\
\hline
\end{tabular}


Table 2: The TC/HDL-C ratio of the non- users and users of hormonal contraceptives.

\begin{tabular}{lccc}
\hline Age & $\mathbf{1 6 - 2 5}$ years & $\mathbf{2 6 - 3 5}$ years & $\mathbf{3 6 - 4 5}$ years \\
\hline Non users & 2.12 & 2.0 & 2.31 \\
Users & 1.65 & 1.67 & 1.72 \\
\hline
\end{tabular}

Table 3: The LDL-C/HDL-C ratio of the non- users and users of hormonal contraceptives.

\begin{tabular}{lccc}
\hline Age & $\mathbf{1 6 - 2 5}$ years & $\mathbf{2 6 - 3 5}$ years & $\mathbf{3 6 - 4 5}$ years \\
\hline Non users & 0.84 & 0.82 & 1.09 \\
Users & 0.46 & 0.50 & 1.72 \\
\hline
\end{tabular}

\section{Conclusion}

The significant change in levels of Total Cholesterol and High-Density Lipoprotein- Cholesterol among women on hormonal contraceptives within the age range of 26-35 years suggests that the administration of hormonal contraceptives can offer a cardio -protective effect on women within this age range than any other age group.

\section{REFERENCES}

Adekunle AO, Fakokunde AF, Arowojolu AO, Ladipo OA. 2000. The effects of normegestrol acetate sub dermal implant (uniplant) on serum cholesterol, triglycerides, and lipoproteins in Nigerian users. Contraception, 61(2): 139-144.

Aldrighi JM, Petta CA, Bahamondes L, Caetano ME, Martinez TR, De Lima GR. 2004. Lipid profile in women over 35 years old using triphasic combined oral contraceptives. Contraception, 69(5): 395-399.

Barr DP, Russ EM, Eder HA. 1951. ProteinLipid Relationships and Related Conditions II. In arteriosclerosis and related conditions. American Journal of Medicine. II: 480 - 493.

Benagiano G, Primiero FM, Bastianelli C, Biandii P, Medda E. 1997. Comparative clinical evaluation of the effect on carbohydrate and lipid metabolism of two northisterone - containing hormonal contraceptives; Mesigyna and GriNovum. Contraception. 55(5): 295-300.
Brezinka, V, Padmos I. 1994. Coronary Heart Disease Risk Factors in Women. European Heart Journal, II: 1971-1584.

Cromie MA, Maile MH, Waiszczuk CP. 2000. Comparative effects of Lunelle monthly contraceptive injection (megroxyprogesterone acetate and estradiol cypionate injectable suspension) and ortho-Novum 7/7/7 oral contraceptive (norethindrone/ ethinyl estradiol triphasic) on lipid profiles. Contraception, 61(1): 51-59.

Evans, Forinash. 2003. New hormonal contraceptives: MedroxyprogesteroneEstradiol Cypionate Injection. Pharmacotherapy, 23(12): 1-3.

Guazzelli CA, Lindsey PC, de Araujo FF, Barbieri M, Petta CA, Aldrighi JM. 2005. Evaluation of lipid profile in adolescents during long-term use of combined oral hormonal contraceptives. Contraception, 71(2): 118-121.

Helena FD, Arvi L, Lars-Ake M, Eva W, Goran K, Dan M, Tore S, Claes O, Elisabeth N, Hans C. 2003. Influence of hormone replacement therapy on disease progression and bone mineral. Journal of Rheumatology, 30(7): 14561463.

LaRosa JC. 1989. Effects of Oral Contraceptive on Circulating Lipids and Lipoproteins: Maximizing Benefit, Minimizing Risk. International Journal of Fertility, 34 (Supplement): 71.

Lech MM. 2003. Depot medroxyprogesterone acetate (DMPA) injectable contraception- 
Safe, effective but neglected method of family planning in Poland. Wiad Lek., 56(7-8): 362-368.

Lobo RA, Skinner JB, Lippman JS, Grillo SJ. 1996. Plasma Lipids and Desogestrel and Ethinyl Estradiol. A meta-analysis. Fertility and Sterility, 65: 1100.

Moutos DM, Zacur HA. Bachorik PS, Wallach EE. 1994. Lipoprotein Alteractions from a Triphasic Oral Contraceptive Containing Ethinyl Estradiol and Gestodene. A 12 - Months' trial. Journal of Reproductive Medicine 39(9): $720-724$.

Nikkila E. 1953. Studies on Lipid - Protein Relationships in normal and Pathological Sera and the Effect of Heparin on Serum Lipoproteins Scand. Journal of Clinical Laboratory Investigation, 5: 1- 101.

Ottoson UB. 1984. Oral Progesterone and Oestrogen/Progestogen Therapy. Effects of National and Synthetic Hormones on Sub fractions of HDL - Cholesterol and Liver Proteins. Acta Obstetric.
Gynecology. Scand, 127 (Supplements): 1-37.

Sheu WH, Hsu CH, Chen YS. Jengv CY, Fuh MM. 1994. Prospective evaluation of insulin resistance and lipid metabolism in women receiving oral contraceptives. Clinical Endocrinology (Oxford), 40(2): 249-255.

Speroff L, Darney PA. 1992. Clinical Guide for Contraception. Williams and Wilkins: Baltimore, $75 ; 2$.

Stadel BV. 1981. Oral Contraceptive and Cardiovascular Risk. N. England Journal of Medicine, 305: 672 - 677.

Teichman A. 1995: Metabolic Profile of Six Oral Contraceptives Containing Norgestimate, Gestodene and Desogestrel. International Journal of Fertility - Menopause, 40 (Supplements 2): $98-104$.

Waine H, Frieden EH, Caphn II, Cole T. 1963. Metabolic effects of enovid on rheumatoid patients. Arthritis Rheum, 6: $796-800$. 